\title{
MESIN PENGOLAH SAMPAH PORTABEL MULTIGUNA DENGAN TEKNIK TERMOCONTROL DAN TERMOCOPLE
}

\author{
Agus Ganda Permana ${ }^{1)}$, dan Muhammad Iqbal') \\ 1,2D3 Teknik Telekomunikasi, Fakultas Ilmu Terapan, Universitas Telkom \\ 1,2,J1. Telekomunikasi Jl. Terusan Buah Batu, Sukapura, Kec. Dayeuhkolot, Bandung, Jawa Barat 40257 \\ E-mail : agusgandapermana@telkomuniversity.ac.id ${ }^{1)}$,iqbal@tass.telkomuniversity.ac.id ${ }^{2)}$
}

\begin{abstract}
ABSTRAK
Sampah merupakan salah satu masalah lingkungan yang kerap terjadi di tengah masyarakat, masalah ini tidak hanya di desa bahkan negara maju pun tidak terlepas dari masalah ini. Beberapa masalah seperti kebutuhan lahan tempat pembuangan akhir (TPA) yang meningkat karena gagalnya pengelolaan sampah secara efektif dan efisien, permasalahan kesehatan dan lingkungan seperti proses pembakaran terbuka sehingga menimbulkan dampak buruk kepada warga sekitar akibat asap dan bau yang menyengat, kualitas air yang dihasilkan pun menurun sehingga masyarkat lebih banyak terserang penyakit.

Teknologi alternatif dalam penelitian ini adalah mengembangkan pengelolaan sampah secara modern, mesin incinerator ini bekerja dengan proses melakukan pembakaran di ruang tertutup secara optimal dan sempurna, sehingga sampah yang dibakar menjadi abu yang dapat digunakan kembali atau ramah lingkungan. Mesin pengolah sampah portabel ini dilengkapi dengan sistem pengendalian (Burner) dan control (Termocontrol \& Termocople) untuk memenuhi batas-batas emisi partikel dan gas buang. Incenerator ini menggunakan proses pengolahan sampah dengan cara pembakaran pada temperatur $400-600^{\circ} \mathrm{C}$, sedangkan invensi pada penelitian ini adalah proses filterisasi membutuhkan suhu $400-1200^{\circ} \mathrm{C}$ dipastikan asap yang keluar dari tempat pembakaran sampah merupakan gas yang sudah netral dan bersifat smokeless (tanpa asap). Abu yang dihasilkan dari proses pembakaran bisa digunakan untuk bahan bangunan, dibuat bahan campuran kompos atau di buang ke landfill. Sedangkan residu dari sampah yang tidak dapat dibakar seperti sisa logam bisa di daur ulang, sehingga produk ini cocok untuk swakelola tempat olah sampah setempat (TOSS).
\end{abstract}

Kata Kunci: Sampah, TPA, Portabel, Incinerator, Smokeless, TOSS

\section{PENDAHULUAN}

Setiap manusia yang berada pada jaman sekarang pasti hidup dengan menghasilkan sampah, sementara sampah perlu mencari lokasi penimbunan sampah yang besar, bukan merupakan perkara mudah mencari tempat banyak penolakan dari masyarakat terkait keberadaan TPA, hingga teknologi yang akan digunakan untuk mengolah sampah tersebut. Pada dasarnya ada dua alternatif proses pengolahan sampah menjadi energi, yaitu proses biologis yang menghasilkan gas-biogas dan proses thermal yang menghasilkan steam. Teknik pengelolaan sampah di kota-kota di Indonesia masih dilakukan secara konvensional, yaitu metode open dumping dan timbunan (sanitary landfill) pada prakteknya pengelolaan sampah menimbulkan beberapa permasalahan. Kebutuhan lahan TPA yang cepat meningkat akibat tidak dilakukannya proses reduksi volume sampah secara efektif. (Trisyanti, 2018) mengatakan bahwa $69 \%$ sampah Indonesia berakhir di TPA dari total 65 juta ton setiap hari. Berbagai permasalahan lingkungan dan kesehatan, mulai dari yang ringan hingga berat seperti bau yang menyengat hingga potensi sebaran penyakit di daerah sekitar TPA. (Ramadhan, 2019) penyakit yang ditimbulkan oleh sampah antara lain hepatitis, kolera, disentri, penyakit kulit, tifoid, dan pencemaran kualitas air.

Teknik reduksi konvensional dengan cara dibakar langsung memberikan dampak buruk ke atmosfer berupa polusi gas-gas rumah kaca dan gas beracun lainnya. Teknologi incinerator yang digunakan dalam sistem pembangkit listrik tenaga sampah (PLTSa), dapat menimbulkan banyak permasalahan, seperti senyawa kimia sangat beracun terbentuk pada proses pembakaran sampah yang tidak terkontrol, terlebih lagi sampah heterogen. Hasil emisi yang paling berbahaya pada pembakaran sampah heterogen ialah terbentuknya senyawa dioksin dan furan, senyawa ini sangat berbahaya bagi kesehatan tubuh manusia.

Peran masyarakat dalam menanggulangi permasalahan sampah sebenarnya sudah mulai terlihat dalam beberapa kajian seperti (Agus, Oktaviyanthi, \& Sholahudin, 2016) melakukan sosialisasi pengolahan sampah rumah tangga dan pelatihan pembuatan kerajinan tangan dari koran bekas, sehingga dapat mengurangi limbah rumah tangga. Kemudian (Puji, Dicky, \& Usdek, 2018) melakukan sosialisasi kepada masyarakat sasar untuk membantu warga mengolah limbah sampah plastik, menjadi produk yang bisa dijual dan menghasilkan produk yang memiliki nilai tambah. 
Bahkan menurut (Zulfinar \& Sembiring, 2015), perkembangan besar kecilnya sampah diwarnai oleh perkembangan jumlah penduduk, pertumbuhan ekonomi, standar hidup yang tinggi terutama di kota menengah dan besar, sektor informal dan perilaku masyarakat.

Sebagai hasil riset kemitraan dan binaan perguruan tinggi PT. Megah Ganda Utama (melalui salah satu Program Studi Fakultas Ilmu Terapan dan Bandung Techno Park, Universitas Telkom) dengan keluaran berupa produk yang sudah diuji di laboratorium Sucopindo dan lapangan (Kurniawan, 2019), dan sudah membentuk satuan tugas dalam menjaga kebersihan sungai Citarum, Bandung khususnya dalam pengelolaan sampah (Sari, 2019).

Maka dirasa penting bagi kami dalam berupaya untuk melakukan pengembangan terus menerus yang dilakukan secara tahapan-tahapan sesuai kebutuhan di lapangan diantaranya meliputi penyesuaian user interface aplikasi kontrol yang telah di desain sebelumnya, perbaikan fitur-fitur backend, untuk mempermudah monitoring, dokumentasi data, personalisasi data per user, perancangan prototype casing untuk perangkat keras dengan memperhatikan nilai-nilai ergonomis dan estetika dan lain sebagainya sampai produk benar-benar siap dan layak untuk digunakan sesuai sasarannya.

Gambar 1. menunjukkan diagram alir dalam pengelolaan sampah, peran swakelola masyarakat masih dibutuhkan dalam hal pemisahan dan pemilahan, sehingga sampah akan dibedakan menjadi sampah organik dan anorganik, yang keduanya dibedakan antara sampah yang dapat di daur ulang dan tidak, terutama untuk sampah organik jika layak untuk sampah kompos akan diresidu dengan menggunakan sistem incinerator, sehingga hasil akhir akan berdaya guna untuk dijadikan pupuk alami (kompos) hasil residu pembakaran.

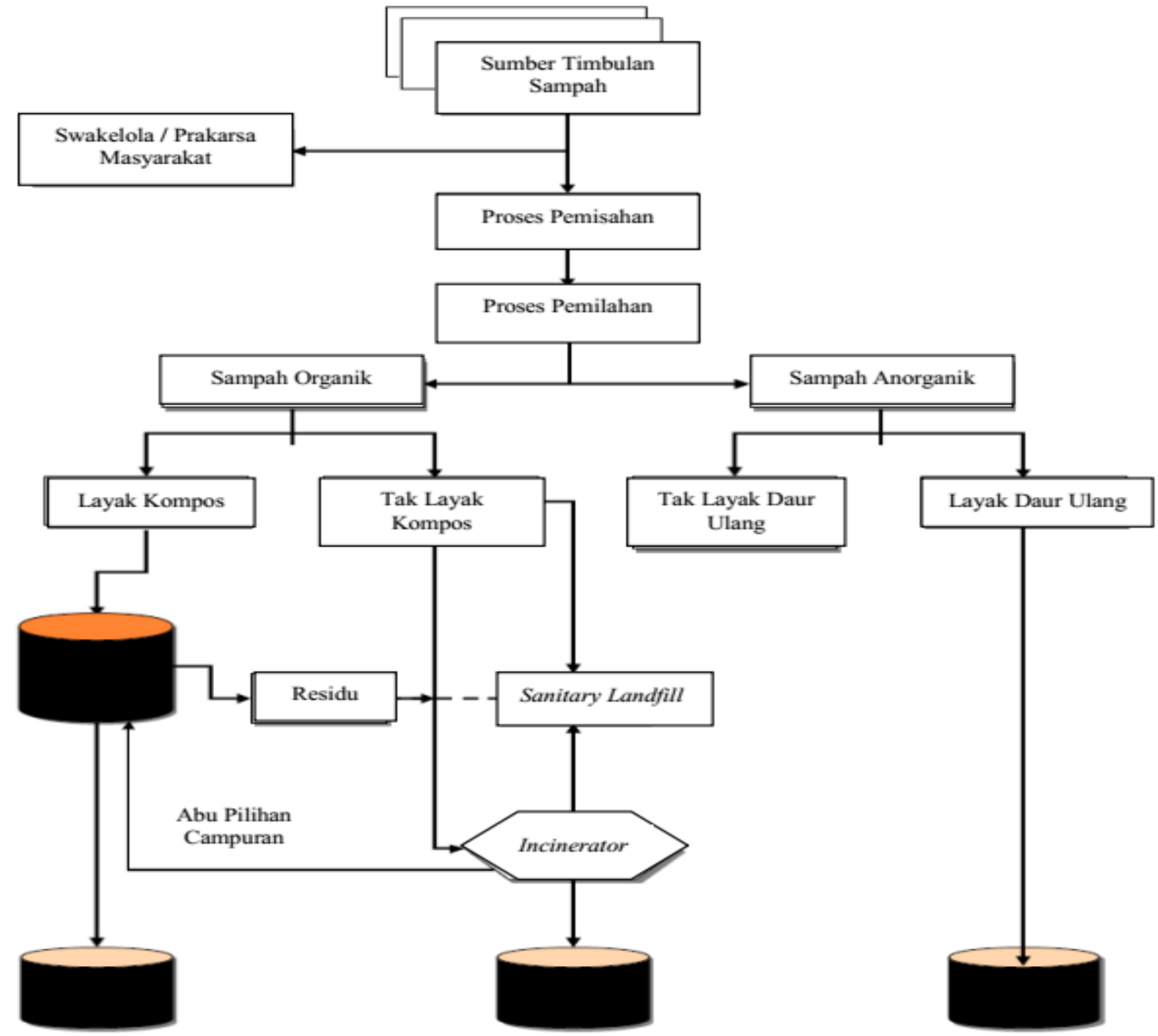

Gambar 1. Diagram alir Pengelolaan Sampah (Murarka I.P., 1987) 
Dalam paper ini akan dikaji tentang pendahuluan yang merupakan latar belakang masalah, mengkaji penelitian-penelitian sebelumnya, kemudian mambahas juga tentang aspek teknis dan bahan baku yang digunakan. Bab 3 membahas tentang aspek pengembangan produk dan keterbaruan inovasi. Bab 4 membahas tentang hasil penelitian dan pembahasan dan Bab 5 merupakan kesimpulan dari seluruh pembahasan. Dan yang terakhir adalah peneliti memberikan saran terkait tempat olah sampah ini untuk kedepannya yang lebih baik.

\section{RUANG LINGKUP}

Dalam penelitian ini dikembangkan terkait dengan spefisifikasi teknis dan ketersediaan bahan baku.

Aspek teknis dalam penelitian ini merupakan suatu yang berkenaan dengan proses pembangunan sistem mesin portable incinerator secara detail teknis dan pengoperasiannya setelah dibangun.

Analisis teknis dapat diketahui rancangan awal penaksiran biaya investasi termasuk biaya eksploitasinya. Pelaksanaan dari evaluasi aspek teknis sering tidak memberikan suatu keputusan baku. Oleh karena itu perlu diperhatikan suatu atau beberapa pengalaman dari penelitian sebelumnya yang serupa dengan menggunakan teknik dan operasi serupa (Hiskawati, 2018). Keberhasilan penggunaan teknologi sejenis ditempat lain sangat membantu dalam pengambilan keputusan akhir (Rhohman \& Ilham, 2016), setidaknya memperhatikan pengalaman ditempat lain tidak bisa dikesampingkan.

Dalam memahami sebuah studi kelayakan pada aspek teknis, ada baiknya terlebih dahulu kita memahami mengenai pengertian, maksud dan tujuan serta fungsi dari sebuah studi kelayakan pada aspek teknis. Berikut merupakan detail teknis yang terkait mesin portable incinerator

\subsection{Spesifikasi Teknis}

Incinerator merupakan sebuah tungku atau wadah pembakaran untuk mengolah limbah atau sampah dalam bentuk padat yang dikonversi menjadi bentuk gas dan abu. Dengan kata lain, alat ini merupakan mesin penghancur limbah organik dan non-organik melalui pembakaran dalam suatu sistem yang terkendali dan terisolasi dari lingkungan terdekat. Temperatur incinerator bersuhu tinggi yang kemudian di kontrol oleh pengolahan termal. Pada tahap akhir gas yang dihasilkan oleh sisa pembakaran dibersihkan dari polutan sebelum terbang ke atmosfer langit dengan sistem smokeless atau tanpa luaran asap. Sampah yang terbakar dari senyawa organik sederhana menjadi senyawa $\mathrm{H}_{2} \mathrm{O}$ dan $\mathrm{CO}_{2}$. Energi panas yang dihasilkan dari proses pembakaran dapat dipakai kembali sebagai energi alternatif lainnya seperti pengeringan dan pemanasan. Mesin ini juga dapat menghasilkan sisa pembakaran yang lebih steril sehingga aman ketika limbah sisa pembakaran ini dibuang ke tanah.
Data teknis incinerator solair, mengolah limbah domestik dengan sistem rotary incinerator dan sistem aliran gas :

1. Rangka Body meliputi kapasitas volume sampah dengan variasi $30 \mathrm{~kg} / \mathrm{Jam}$ sampai dengan 300 kg/jam; Coran Bata Api, Roda, Reservoar air, Burning Chamber Berbahan Bakar SOLAR + AIR (Hidrogen)

2. Rotary Set meliputi Electro Motor $1 \mathrm{HP}, 750$ Watt; Gear box, rantai dan belt; Besi Screw

3. Burner Set meliputi Suhu Bakar $400^{\circ} \mathrm{C}-1200^{\circ} \mathrm{C}$; Konsumsi Bahan Bakar: Solar 3 Ltr/jam, Air 9 Ltr/jam; Tabung Solair, Tabung Gas Pematik Api ukuran $3 \mathrm{~kg}$; Kompresor $250 \mathrm{~W}$

4. Treatment set meliputi Abu \pm 5 dari volume limbah; Smokeless, Non-Toxin; Pompa Air 125 Watt; Pipa 1 inch steinless + elbow; Filter Set; Blower Set 750 watt

5. Kelistrikan dan Kontrol meliputi Panel Listrik; Pengontrol Suhu; Pewaktu; Pengontrol Solair; Sistem EBT 1300 Watt

Gambar 2. Tipe incinerator yang memiliki kapasitas $200 \mathrm{~kg} / \mathrm{jam}$, sehingga dapat memuat lebih banyak daya tampung sampah ke dalam mesin pengolah sampah. Walaupun memiliki kapasitas yang lebih besar, perlu diperhatikan tentang kekuatan besi karena panas yang dihasilkan dalam ruang incinerator, sehingga perlu dimodifikasi yang lebih baik lagi.
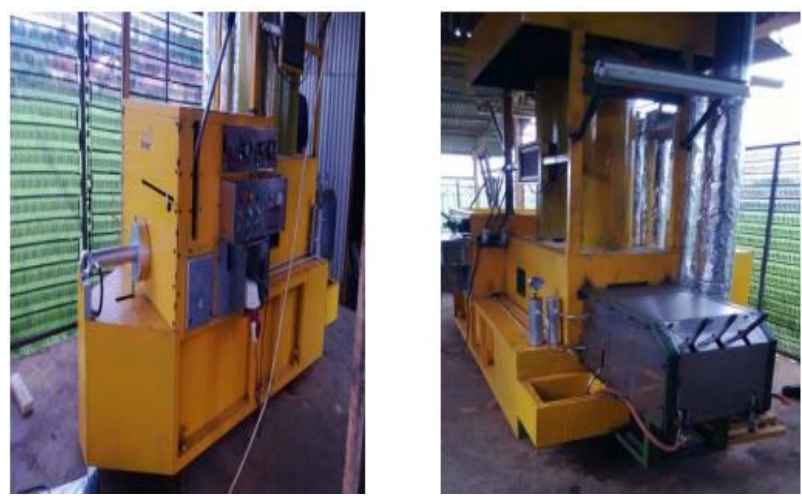

\section{Gambar 2. Incinerator SOLAIR skala pasar kapasitas $100 \mathrm{Kg} / \mathrm{Jam}$}

Gambar 3 merupakan tipe incinerator yang bersifat mobile, sehingga dapat dibawa dengan mudah untuk mengatasi permasalahan di berbagai wilayah. Dengan kapasitas $30 \mathrm{~kg} / \mathrm{jam}$. Pada tipe ini incenarator sudah besifat smokeless dan kandungannya gasnya sudah bersifat netral. 

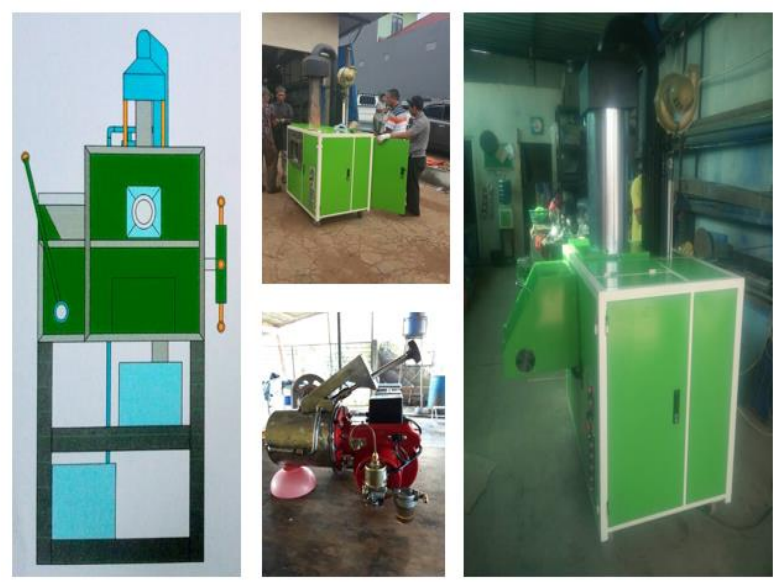

Gambar 3. Model Incinerator SOLAIR Casing Press Body Skala RT/RW Kapasitas 30 kg/jam

\subsection{Ketersediaan Bahan Baku}

Ketersediaan bahan baku untuk memproduksi produk teknologi smart incinerator cukup melimpah, berikut merupakan hasil survey team terkait dengan suku cadang peralatan yang berada dipasaran baik pasar lokal maupun online (marketplace)

Pada Tabel 1. terlihat bahwa ketersediaan perangkat yang dibutuhkan untuk membuat mesin pengolah sampah portable ini cukup banyak berada dipasaran seperti rangka body, rotary set, burner set, treatment set, kelistrikan dan kontrol, sehingga pembuatan mesin ini jika ada permintaan yang bersifat dalam jumlah banyak dapat tersedia dengan mudah. Ada beberapa bagian yang dilakukan secara manual untuk mendukung peralatan ini, namun bahan baku masih tersedia banyak juga di pasar, seperti kolaborator yang terbuat dari bahan dasar osmium.

Kesimpulan pada tabel 1 ini hampir semua komponen tersedia di pasar, hanya sebagian kecil komponen dirakit sendiri, itu pun bahan dasar yang digunakan juga tersedia di pasaran.

Tabel 1. Komponen Suku Cadang

\begin{tabular}{|c|c|c|c|}
\hline \multirow[t]{2}{*}{ \# } & \multirow[t]{2}{*}{ Komponen } & \multicolumn{2}{|l|}{ Bahan Baku } \\
\hline & & $\begin{array}{l}\text { Spesifikasi } \\
\text { Standar }\end{array}$ & $\begin{array}{l}\text { Ketersediaan } \\
\text { Pasar }\end{array}$ \\
\hline \multirow[t]{4}{*}{1} & Rangka Body & & \\
\hline & Plat Besi & $1,4 / 2 \mathrm{~mm} / 6 \mathrm{~mm}$ & tersedia \\
\hline & Besi & $\begin{array}{l}\text { CNP } \\
5 \times 5 / 8 \times 8 / 10 \times 10\end{array}$ & tersedia \\
\hline & Bata Api & P20 & tersedia \\
\hline \multirow[t]{6}{*}{2} & Rotary Set & & \\
\hline & Electro Motor & $1 \mathrm{PK}, 750 \mathrm{~W}$ & tersedia \\
\hline & Gear Box & 60 putaran & tersedia \\
\hline & $\begin{array}{l}\text { Rantai } \\
\text { Penghubung }\end{array}$ & $7 / 8$ inch & tersedia \\
\hline & Belt & B double & tersedia \\
\hline & Besi Screw & 4 inch & tersedia \\
\hline \multirow[t]{3}{*}{3} & Burner Set & & \\
\hline & Casing Burner & stainless & tersedia \\
\hline & Kolaborator & Terbuat dari & Buat sendiri \\
\hline
\end{tabular}

\begin{tabular}{|c|c|c|c|}
\hline & & osmium & \\
\hline & Air & Jernih & tersedia \\
\hline & Blower & 2 inch & tersedia \\
\hline & Solar & Bio Solar & tersedia \\
\hline & Tabung & 10 liter & tersedia \\
\hline & Kompresor & $1 \mathrm{PK}, 750 \mathrm{~W}$ & tersedia \\
\hline 4 & Treatment Set & & \\
\hline & Penampung air & $\begin{array}{l}\text { Plat besi } \\
20 \times 20 \times 40 \mathrm{~cm}\end{array}$ & tersedia \\
\hline & Pompa air & $125 \mathrm{~W}$ & tersedia \\
\hline & Pipa cerobong & Pipa besi 4 Inch & tersedia \\
\hline & Pipa air & $\mathrm{PVC} 1 / 2$ & tersedia \\
\hline & Nozel air & $3 \mathrm{~mm}$ & tersedia \\
\hline 5 & Kontrol & & \\
\hline & Panel Listrik & Manual/auto & tersedia \\
\hline & $\begin{array}{l}\text { Pengontrol } \\
\text { Suhu }\end{array}$ & Manual/auto & tersedia \\
\hline & $\begin{array}{l}\text { Pengontrol } \\
\text { Solair }\end{array}$ & Manual/auto & tersedia \\
\hline
\end{tabular}

\section{BAHAN DAN METODE}

Penelitian tentang swakelola tempat olah sampah setempat (TOSS) selalu mengalami perkembangan di lapangan untuk mendapatkan hasil yang yang ideal. Bahkan bukan tidak mungkin permasalahan yang terjadi dapat diselesaikan dengan mendapatkan ide dari alam kembali. Berikut merupakan tahapan pengembangan produk dan keterbaruan produk inovasi.

\subsection{Tahapan Pengembangan Produk}

Untuk menjaga keberlangsungan hidup sebuah penelitian, penulis harus senantiasa mengembangkan produknya, apakah dengan membuat produk yang benarbenar baru, meremajakan produk yang sudah ada, menambahkan fitur atau fungsi baru, atau bisa jadi menciptakan produk baru yang merupakan pengembangan dari penelitiannya.

Dengan mengembangkan produk baru, maka siklus hidup produk bisa dijaga agar tetap dalam masa pertumbuhan dan kedewasaan, artinya saat ada item produk yang mengalami penurunan (decline), peneliti sudah memiliki produk lain sebagai subtitusi di segment tersebut.

Mengembangkan produk baru juga berfungsi untuk memperlebar segment pasar, dengan menciptakan produk baru untuk market segment baru yang berbasis pada produk lama. Mengembangkan produk baru, bukan sesuatu hal yang mudah, banyak sekali produk baru yang di rilis atau diluncurkan perusahaan gagal, mati ditengah jalan, bahkan beberapa sebelum masa bertumbuh.

Untuk meminimalkan resiko kegagalan pengembangan produk baru, bukan saja harus memikirkan strategi pengembangan produk baru, tetapi harus juga memahami dan menjalankan setiap tahapan dalam proses pengembangan produk barus tersebut.

Berikut adalah 8 tahap proses pengembangan produk baru (8 steps of new product development process) (Octa, 2019) agar bisa menghasilkan produk yang unggul dalam persaingan di pasar, yaitu : 
1. Penciptaan ide produk

2. Penyaringan atau pemilihan ide produk

3. Pengembangan dan pengujian konsep

4. Pengembangan strategi pemasaran

5. Analisa bisnis

6. Pengembangan produk

7. Uji pemasaran (skala kecil)

8. Komersialisasi

Sementara hasil dari pengembangan produk untuk mesin pengolah sampah ini dikaitkan dengan kondisi lingkungan yang nyata maka dapat dijelaskan pada Gambar 4. Tahapan Pengembangan Produk, Dijelaskan terkait dengan pengembangan produk yang dibagi menjadi 6 bulan. Bulan ke-1, mendesain konstruksi mekanisme alat dan desain market, bulan ke-2 melakukan pematangan dan pengembangan konsep sehingga perlu dilakukan pendampingan dan perbaikan sistem dalam bentuk pelatihan dan training. Dan pada bulan ke-3 sampai dengan bulan ke-6, melakukan perancangan konsep promosi kepada publik, implementasi produk dan duplikasi produk, membentuk unit usaha di lingkungan akademik kampus dan tahap terakhir yang dilakukan adalah melakukan diseminasi hasil penelitian yang telah dilakukan.

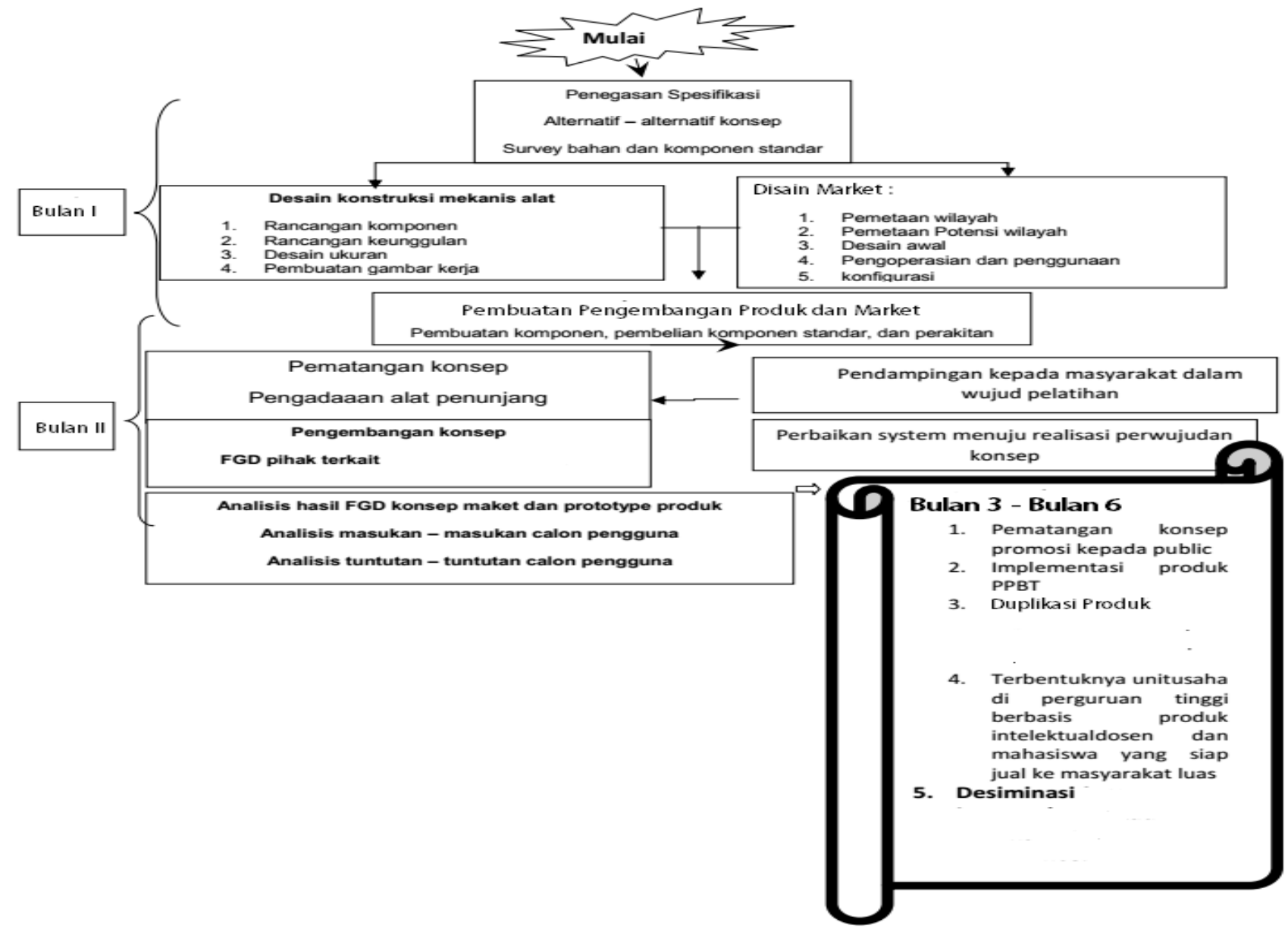

Gambar 4. Tahapan Pengembangan Produk

\subsection{Keterbaruan Produk Inovasi}

Usaha penanggulangan sampah, baik dari rumah tangga/penduduk, industri, rumah sakit maupun dari sumber lainnya telah banyak dilakukan berbagai pihak dengan beragam pendekatan teknologi seperti: penimbunan, daur- ulang, pengkomposan, fermentasi, insinerasi dan gasifikasi, ternyata masih belum mencapai sasaran dengan berbagai kendalanya masingmasing.

Penanggulangan sampah yang belum optimal di berbagai kota besar dan metropolitan bukan saja akan memperburuk keindahan kota tapi juga akan menimbulkan bau, pencemaran air dan udara, penyakit, banjir, dan sebagainya.

Pada Tabel 2. dijelaskan bahwa sampah rumah tangga menjadi penyumbang terbesar sebanyak $48 \%$, sisanya oleh yang lain seperti pasar, pertokoan, sarana umum, dan lain-lain. Sementara jenis sampah yang dihasilkan sebanyak 65\% untuk sampah organik. Dari hasil ini menjadi peluang bahwa sampah organik yang masuk ke mesin incinerator akan dapat recycle kembali. 
Tabel 2. Sumber dan Komposisi Sampah

\begin{tabular}{|l|l|l|l|}
\hline $\begin{array}{l}\text { Sumber } \\
\text { Sampah }\end{array}$ & $\%$ & $\begin{array}{l}\text { Komposisi } \\
\text { Sampah }\end{array}$ & $\%$ \\
\hline Rumah Tangga & 48 & Bahan organik & 65 \\
\hline Pasar & 24 & Kertas & 13 \\
\hline Pertokoan & 6 & Kayu & 3 \\
\hline Sarana Umum & 6 & Barang Industri & 1 \\
\hline Jalan & 6 & Karet & 1 \\
\hline Industri & 2 & Plastik & 11 \\
\hline Perkantoran & 2 & Logam & 2 \\
\hline Lainnya & 6 & Lainnya & 4 \\
\hline
\end{tabular}

Salah satu teknologi alternatif telah dikembangkan untuk menangani permasalahan sampah dalam skala mikro hingga makro adalah incinerator. Teknologi incinerator bekerja dengan cara membakar sampah secara optimal dengan pembakaran sempurna hingga sampah menjadi abu yang ramah lingkungan.

Incinerator merupakan suatu alat atau mesin untuk membakar sampah mengunakan teknologi pembakaran yang di design sedemikian rupa dengan temperatur tertentu sehingga sisa pembakaran sangat minim. Teknologi incinerator menggunakan teknologi yang mengkonversi materi padat (dalam hal ini sampah) menjadi materi gas (gas buang), serta materi padatan yang sulit terbakar, yaitu abu (bottom ash) dan debu (fly ash) dengan metode pengolahan sampah dengan cara membakar sampah pada suatu tungku pembakaran.

Gambar 5. Merupakan proses pembakaran pada sistem incinerator yang dimulai dari tahap pemasukan sampah lalu ke tempat penampungan sampai dengan proses akhir yang semuanya di bantu dengan generator.

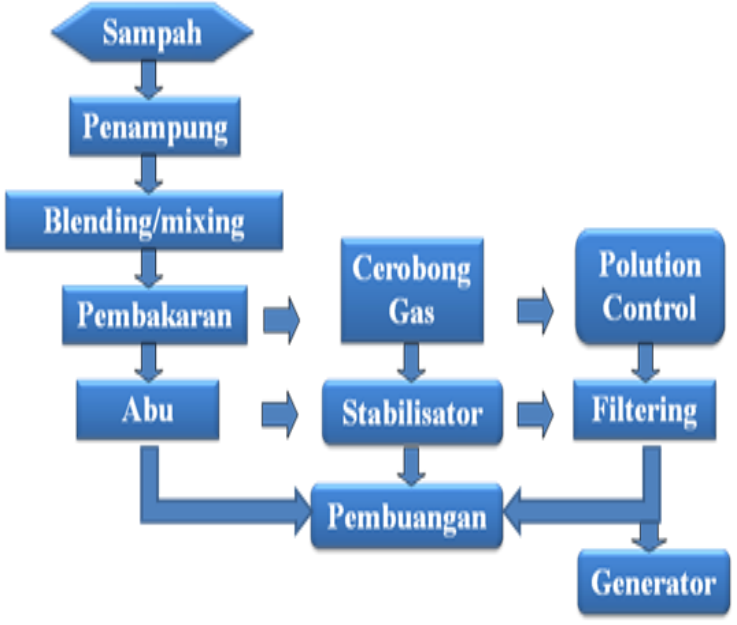

Gambar 5. Proses Pembakaran Sistem Incinerator

\section{PEMBAHASAN}

Alat ini dapat dilengkapi dengan sistem pengendalian (oleh Burner) dan control (oleh Termocontrol \& Termocople) untuk memenuhi batas-batas emisi partikel dan gas buang, sehingga dipastikan asap yang keluar dari tempat pembakaran sampah merupakan asap/gas yang sudah netral (bukan hanya Smokeless).

Abu yang dihasilkan dari proses pembakaran bisa digunakan untuk bahan bangunan, dibuat bahan campuran kompos atau dibuang ke landfill. Sedangkan residu dari sampah yang tidak bisa dibakar seperti sisa logam bisa di daur ulang. Incenerator menggunakan proses pengolahan sampah dengan cara pembakaran pada temperatur $400-600^{\circ} \mathrm{C}$, sedangkan untuk pembakaran filterisasi dibutuhkan temperature antara $400-1200^{\circ} \mathrm{C}$, dari suhu yang seperti ini menghasilkan gas yang aman bagi kesehatan, selain tidak adanya aap yang keluar melalui cerobong asap.

Gambar. 6, Produk Incinerator tersebut diatas telah banyak digunakan di berbagai kota di Indonesia, akan tetapi incinerator yang digunakan masih belum optimal, tidak hanya mahal karena harganya sampai milyaran rupiah akan tetapi juga belum dapat menjawab semua permasalahan yang berhubungan dengan sampah dan lingkungan. Umumnya alat ini didatangkan dari luar negeri yang harganya mencapai milyaran rupiah, serta membutuhkan tenaga operator maupun teknisi yang terdidik dan terlatih. Incinerator luar ini dalam pengoperasiannya cukup memakan biaya besar karena dalam proses pemusnahan limbah membutuhkan bahan bakar dan listrik yang cukup besar secara kontinyu. Selain itu komponen alat tidak mudah didapatkan dipasaran dalam negeri sehingga cukup merepotkan tatkala terjadi kerusakan dan perawatan.

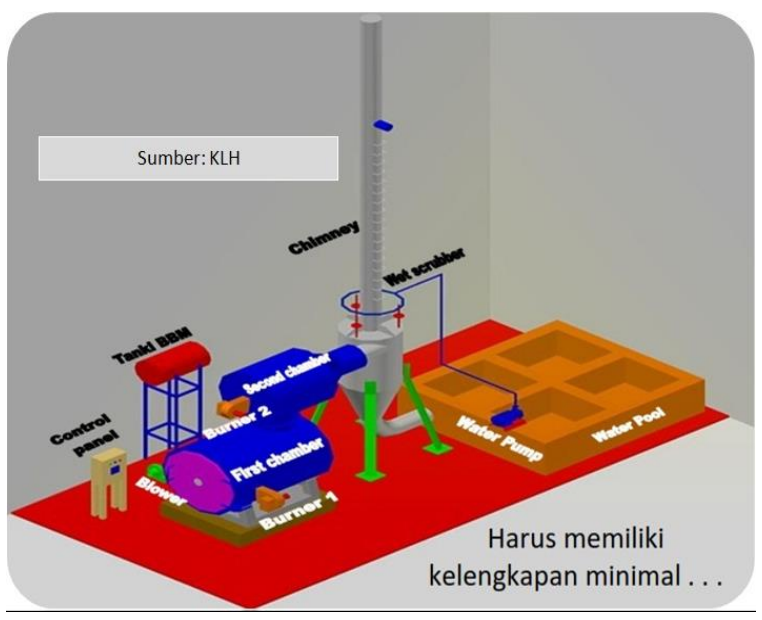

Gambar 6. Sistem Incinerator Standar Minimal

Produk incinerator MOS Multiguna SOLAIR dapat menjawab permasalahan tersebut diatas, alat pembakar sampah ini mampu membakar secara sempurna dan habis menjadi debu sampah yang masuk ke dalam alat incinerator. Pembakaran sempurna berkaitan dengan jumlah oksigen yang masuk ke dalam ruang bakar serta ketepatan pembakaran pertama, panas pembakaran yang diperlukan, Operasi dan perawatan (O\&M) yang murah, mudah dan suku cadang tersedia karena menggunakan EBT terpadu mandiri serta kontrol Elektronik.

Gambar 7. Merupakan tipe incinerator yang mempunyai tipe kecepatan pembakaran sebesar $100 \mathrm{~kg} / \mathrm{jam}$, jenis ini memungkin daya yang lebih banyak lagi dengan mempertimbangkan aspek keamanan dari sisi lingkungan sekitar dan juga alat itu sendiri. 


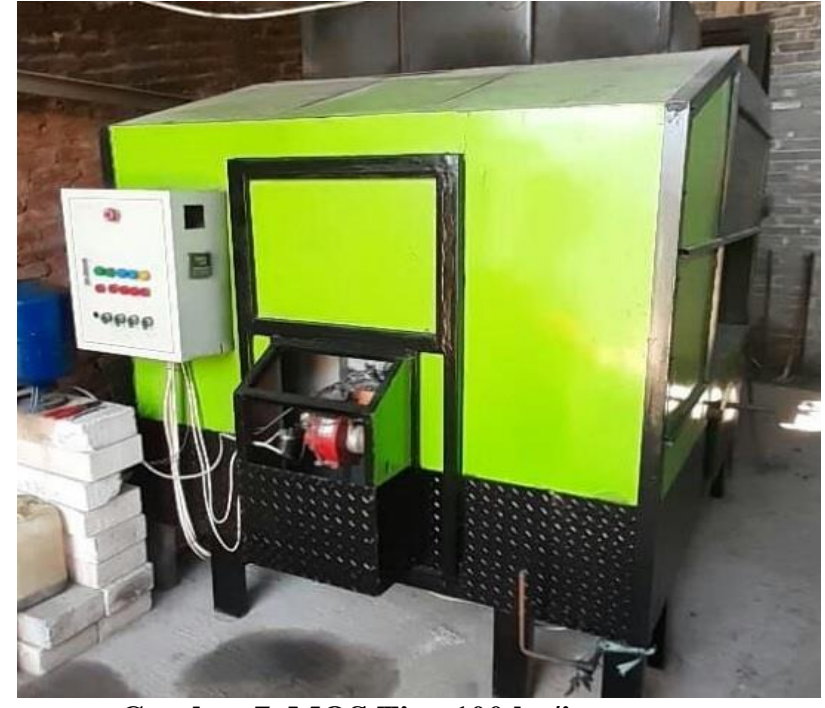

Gambar 7. MOS Tipe 100 kg/jam

Incinerator MOS Multiguna adalah Green Incinerator yang merupakan alat pemusnah sampah ramah lingkungan karena menggunakan BBM minimal kolaborasi AIR dan SOLAR, dapat merubah sampah menjadi gas sintetis, uap dan arang. Selain sampah kota, Green Incinerator SOLAIR dapat juga diaplikasikan untuk sampah/limbah industri yang mungkin beracun, ignitable, korosif atau reaktif baik berbentuk plastik, padat maupun cairan yang mengandung hidrocarbon (seperti oli dan minyak bekas), sehingga alat ini dirancang berdasarkan cara dan tingkatan perlakuan serta karakteristik limbah.

\section{KESIMPULAN}

Dari hasil penelitian yang telah dilakukan mesin incinerator yang diciptakan serta diterapkan pada program Pengabdian Masyarakat dan KKN Tematik Risetdikti dibeberapa kawasan program Citarum Harum sektor 7 dan sektor 21 pada periode tahun 2018 - 2019 memiliki beberapa keuntungan selain tidak membutuhkan ruang dan lahan luas bersifat fixed mobile dan mobile, alat ini juga mampu menghasilkan kecepatan dalam pembakaran sebesar $30 \mathrm{~kg} / \mathrm{jam}$ sampai dengan 300 $\mathrm{kg} / \mathrm{jam}$ sehingga dapat mengolah sampah setempat dan ditempat, tidak mengeluarkan zat yang berbahaya sisa dari pembakaran, tidak mengeluarkan asap (smokeless), dan biaya yang dibutuhkan menjadi lebih murah dibandingkan dengan buatan pabrik. Sementara ada beberapa keuntungan untuk nilai tambah kepada masyarakat, permasalahan sampah di masyarakat bisa teratasi, mengurangi kebiasaan masyarakat membuang sampah di got dan sungai serta di jalan, tidak ada sampah yang menggunung sehingga lingkungan warga menjadi lebih sehat, lingkungan setempat bisa mandiri untuk proses pengelolaan sampah sehingga tidak bergantung pada truk pengangkut sampah, meningkatkan branding sebagai lingkungan bebas sampah, lingkungan menjadi lebih bersih, sehat asri dan kondusif karena tidak ada sampah menumpuk yang menjadi bau dan sarang penyakit, peluang usaha kelompok bersama, kebutuhan tenaga kerja.

\section{SARAN}

Sesuai dengan hasil evaluasi respon yang telah dilakukan, kami menyarankan hendaknya programprogram penelitian dan pengabdian masyarakat terpadu seperti ini dilaksanakan secara reguler dan berkala, melihat tingkat kebutuhan yang tinggi akan pengenalan teknologi tepat guna ramah lingkungan yang baru secara merata di beberapa kawasan (Desa, Kabupten/Kota, Provinsi) sehingga dapat mewujudkan suatu konsep Eco Village atau Living Lab menuju Smart Lingkungan dan Smart Village dalam jangka waktu yang relatif singkat masyarakat juga dapat mengikuti perkembangan teknologi tepat guna ramah lingkungan secara global secara merata.

\section{DAFTAR PUSTAKA}

Agus, R. N., Oktaviyanthi, R., \& Sholahudin, U. 2016. 3R: Suatu Alternatif Pengolahan Sampah Rumah Tangga. KAIBON ABHINAYA, 72-76.

Hiskawati, H. 2018. Rancang Bangun dan Uji Sifat Fisis pada Incinerator Sederhana. Retrieved from http://repositori.uin-alauddin.ac.id/id/eprint/11969

Kurniawan, G. A. 2019. System Tempat Olah Sampah Setempat Terpadu Mandiri Ramah Lingkungan (TOSS TMRL). Retrieved November 20, 2019, from 60 menit.com website: https://www.60menit.com/2019/02/aplikasisystem-toss-tmrl-solair-dalam.html

Murarka I.P. 1987. Solid Waste Disposal and Reuse. Press.Florida, Volume I(CRC).

Octa, A. 2019. Proses Pengembangan Produk Baru (New Product Development) | DISTRIBUSI PEMASARAN dotcom. Retrieved November 13, 2019, from Marketing Strategy website: https://distribusipemasaran.com/8-tahap-prosespengembangan-produk-baru-new-productdevelopment-process/

Puji, N., Dicky, L., \& Usdek, W. 2018. IbM Bank Sampah Desa Mojorejo Kota Batu. MATAPPA: Jurnal Pengabdian Kepada Masyarakat, 1, 23-27.

Ramadhan, T. 2019. Daftar Penyakit Akibat Kebiasaan Buang Sampah Sembarangan - Health Liputan6.com. Retrieved November 13, 2019, from

https://www.liputan6.com/health/read/3902343/daf tar-penyakit-akibat-kebiasaan-buang-sampahsembarangan

Rhohman, F., \& Ilham, N. 2016. Analisa dan evaluasi rancang bangun insinerator sederhana dalam mengelola sampah rumah tangga. Ojs.Unpkediri.Ac.Id. Retrieved from http://ojs.unpkediri.ac.id/index.php/JMN/article/vie w/13442 
Sari, R. 2019. Satgas Smart Village Desa Lengkong. Retrieved November 20, 2019, from 60 menit.com website:

https://www.60menit.com/2019/04/satgas-smartvillage-desa-lengkong.html

Trisyanti, D. 2018. Riset: 24 Persen Sampah di Indonesia Masih Tak Terkelola. Retrieved November 13, 2019, from CNN website: https://www.cnnindonesia.com/gayahidup/20180425101643-282-293362/riset-24persen-sampah-di-indonesia-masih-tak-terkelola

Zulfinar, Z., \& Sembiring, E. 2015. Dinamika Jumlah Sampah Yang Dihasilkan Di Kota Bandung. Jurnal Tehnik Lingkungan, 21(1), 18-28. https://doi.org/10.5614/jtl.2015.21.1.3

\section{UCAPAN TERIMAKASIH}

TNI (kol. Yusef Dansektor 21 dan Kolaborasi. Purwadi Dansektor 7), Pemerintah Kecamatan Pacet, Desa Lengkong dan Sukamukti serta dinas Lingkungan Hidup Kab. Bandung, PPM Universitas Telkom,

Direktorat Jenderal Penguatan Riset dan Pengembangan Kementerian Riset, Teknologi, dan Pendidikan

Tinggi 